\title{
PENGARUH PENGGUNAAN ALAT SEDERHANA KONVERSI ENERGI MEKANIK DALAM MODEL PEMBELAJARAN POE TERHADAP HASIL BELAJAR SISWA PADA MATERI ENERGI KELAS VII SMPN 15 SIGI
}

\author{
Liska Fajaryani, Sahrul Saehana, I Wayan Darmadi \\ Jurusan Pendidikan MIPA \\ Fakultas Keguruan dan IImu Pendidikan Universitas Tadulako Palu
}

\begin{abstract}
Abstrak - Penelitian ini dilakukan dengan tujuan untuk melihat pengaruh penggunaan alat sederhana dalam model pembelajaran Predict, Observe, Explain (POE) menggunakan metode eksperimen dan model pembelajaran $P O E$ tanpa metode eksperimen pada siswa kelas VII di SMP Negeri 15 Sigi. Jenis penelitian ini merupakan eksperimen kuasi dengan desain the eqivalent pretest-posttest group design. Populasi penelitian ini adalah seluruh siswa kelas VII SMP Negeri 15 Sigi. Teknik Sampling yang digunakan pada penelitian ini adalah Purposive Sampling dengan sampel penelitian adalah kelas VII B sebagai kelompok eksperimen dan kela VII A sebagai kelompok kontrol. Instrumen hasil belajar siswa berupa tes pilihan ganda yang telah divalidkan melalui validitas kontruksi. Tes hasil belajar siswa yang diperoleh menunjukkan bahwa skor rata-rata kelompok eksperimen sebesar 14,91. Dimana hasil ini lebih tinggi dari pada kelompok kontrol yaitu 11,20. Uji hipotesis Uji-t (dua pihak), diperoleh $t_{\text {hitung }}=3,18$ dan $t_{0,975}=2,00$ pada taraf nyata $\alpha=0,05$. Ini berarti bahwa nilai $t_{\text {hitung }}$ berada diluar daerah penerimaan $H_{0}$. Disimpulkan bahwa terdapat pengaruh hasil belajar siswa yang menggunakan alat sederhana dalam model pembelajaran $P O E$ menggunakan metode eksperimen dibandingkan hasil belajar siswa yang menggunakan model pembelajaran POE tanpa metode eksperimen pada siswa kelas VII SMP Negeri 15 Sigi.
\end{abstract}

Kata Kunci : Alat Sederhana, POE (Predict, Observe, Explain), Hasil Belajar Siswa

\section{PENDAHULUAN}

Fisika adalah ilmu yang menjelaskan tentang keadaan yang dijumpai sehari-hari, sehingga menyenangkan untuk dipelajari. Namun, kenyataannya tidak demikian. Banyak siswa yang memandang bahwa fisika adalah pelajaran yang sulit. Hal ini dipengaruhi oleh beberapa faktor yang terkait dalam proses belajar mengajar. Salah satu faktor yang mempengaruhi adalah metode pembelajaran yang digunakan oleh guru. Pemilihan metode pembelajaran yang tepat tentu akan membawa peserta didik menyenangi materi yang diajarkan kepadanya.

Model pembelajaran yang digunakan saat ini masih banyak menggunakan model konvensional. Dan guru masih banyak belum menggunakan media pembelajaran pada saat proses pembelajaran. Sehingga hasil belajar siswa kurang baik.

Hasil belajar siswa merupakan hal yang paling diperhatikan pada proses belajar mengajar. Hal itu menyebabkan banyak model dan media pembelajaran yang diterapkan pada siswa untuk meningkatkan hasil belajar mereka. Apalagi pada mata pelajaran fisika, banyak siswa yang sulit untuk memahaminya, oleh karena itu dibutuhkan model dan media pembelajaran yang cocok untuk meningkatkan hasil belajar siswa. Model pembelajaran Predict, Observe, Explain (POE) merupakan salah satu model pembelajaran yang bisa meningkatkan hasil belajar siswa. Dan banyak alternatif media yang dapat digunakan dalam proses pembelajaran. Media tersebut salah satunya adalah alat peraga sederhana. Seperti alat konversi energi mekanik.

Model pembelajaran $P O E$ digunakan untuk mewujudkan kegiatan belajar mengajar yang berpusat pada siswa, terutama siswa dapat menyampaikan hipotesis mereka berdasarkan permasalahan atau pertanyaan yang diberikan, dan siswa dapat membuktikan sendiri hipotesis yang mereka sampaikan melalui eksperimen, kemudian mendiskusikan fenomena yang telah diamati secara konseptual-matematis, serta membandingkan hasil observasi dengan hipotesis yang mereka sampaikan sebelumnya.

Menurut Restami [1] model pembelajaran $P O E$ dapat mencakup cara-cara yang dapat ditempuh oleh seorang guru untuk membantu siswa dalam meningkatkan pemahaman konsepnya, dan pengetahuan yang diperoleh siswa melekat dalam ingatannya dan hasil belajar siswa meningkat.

Penelitian yang dilakukan Marwiah [2] dalam penelitiannya tentang peningkatan pemahaman belajar fisika pada siswa kelas XD SMAN 9 Palu pemanfaatan alat-alat sederhana dengan menunjukkan bahwa pemanfatan alat-alat sederhana dapat meningkatkan pemahaman dan aktivitas belajar siswa.

Penelitian yang dilakukan Paul [3] dalam model pembelajaran $P O E$ siswa diberi kebebasan memikirkan persoalan fisika yang diajukan dan siswa mencoba membangun pengetahuannya sendiri lewat berpikir, praktik dalam pembelajaran, dan mencari penjelasan.

Adapun perbedaan penelitian ini dengan penelitian sebelumnya adalah penelitian ini pada kelas eksperimen dan kontrol menggunakan 
Pengaruh Penggunaan Alat Sederhana Konversi Energi Mekanik dalam Model Pembelajaran Poe Terhadap Hasil Belajar Siswa pada Materi Energi Kelas VII SMPN 15 Sigi

(Liska Fajaryani)

model pembelajaran $P O E$, hanya saja pada kelas eksperimen menggunakan alat konversi energi mekanik melalui metode eksperimen sedangkan pada kelas kontrol tidak melakukan eksperimen tetapi siswa hanya mengamati animasi yang disediakan. Sedangkan pada penelitian sebelumnya pada kelas eksperimen menggunakan model pembelajaran $P O E$ sedangkan pada kelas kontrol menggunakan model konvensional.

Tujuan penelitian ini adalah untuk mengetahui ada tidaknya pengaruh penggunaan alat sederhana konversi energi mekanik dalam model pembelajaran $P O E$ terhadap hasil belajar siswa pada materi energi kelas VII di SMP Negeri 15 SIGI.

Berdasarkan uraian diatas maka manfaat penelitian ini adalah siswa diharapkan dengan adanya metode eksperimen dapat meningkatkan hasil belajar siswa, dan dengan adanya model pembelajaran POE dapat meperbaiki metode mengajar guru guna memperbaiki tingkat daya pikir (keaktifan) siswa serta penguasaan konsep bagi siswa.

\section{METODOLOGI PENELITIAN}

Penelitian ini merupakan penelitian eksperimen kuasi (semu), dimana desain penelitian adalah the eqivalent pretest-posttest group design, yaitu menggunakan kelas-kelas yang sudah ada sebagai kelompoknya, dengan memilih kelas-kelas yang diperkirakan sama keadaan/kondisinya, dalam hal ini sama berdasarkan tingkat kecerdasan. Teknik pengambilan sampel yang dilakukan adalah teknik Sampling Purposive, yaitu teknik penentuan sampel dengan pertimbangan tertentu [4]. Bentuk desainnya disajikan pada Tabel 1.

TABEL 1. DESAIN PENELITIAN

\begin{tabular}{cccc}
\hline Kelompok & Tes Awal & Perlakuan & Tes Akhir \\
\hline Eksperimen & $\mathrm{O}_{1}$ & $\mathrm{X}$ & $\mathrm{O}_{2}$ \\
\hline Kontrol & $\mathrm{O}_{1}$ & - & $\mathrm{O}_{2}$
\end{tabular}

Keterangan:

$\mathrm{O}_{1}$ : Tes awal

$\mathrm{O}_{2}$ : Tes akhir

$X$ : $\quad$ Perlakuan penerapan alat eksperimen sederhana menggunakan model pembelajaran $P O E$

HASIL DAN PEMBAHASAN

Hasil Penelitian
$1 . \quad$ Hasil belajar Posttest

Adapun data hasil posttest, disajikan pada Tabel 2:

TABEL 2. HASIL ANALISIS DATA POSTTEST HASIL BELAJAR SISWA

\begin{tabular}{ccc}
\hline \multirow{2}{*}{ Uraian } & \multicolumn{3}{c}{ Tes Akhir (Posttest) } \\
\cline { 2 - 3 } & Kelas Eksperimen (VII B) & Kelas Kontrol (VII A) \\
\hline Sampel & 31 & 31 \\
\hline Skor Terendah & 9 & 6 \\
\hline Skor Tertinggi & 20 & 17 \\
\hline Skor Rata-rata & 14,91 & 11,20 \\
\hline Standar Deviasi & 3,47 & 3,29 \\
\hline
\end{tabular}

2. Uji Normalitas

Data hail perhitungan disajikan pada Tabel 3:

TABEL 3. NORMALITAS DISTRIBUSI TES AWAL DAN TES AKHIR PADA KELAS EKSPERIMEN DAN KELAS KONTROL

\begin{tabular}{ccccc}
\hline \multirow{2}{*}{ Uraian } & \multicolumn{2}{c}{ Kelas Eksperimen } & \multicolumn{2}{c}{ Kelas Kontrol } \\
\cline { 2 - 5 } & Tes Awal & Tes Akhir & Tes Awal & Tes Akhir \\
\hline Jumlah siswa & 31 & 31 & 31 & 31 \\
$X_{\text {hitung }}^{2}$ & 4,86 & 7,40 & 6,78 & 4,35 \\
$X_{\text {tabel }}^{2}$ & 7,81 & 7,81 & 7,81 & 7,81 \\
\hline
\end{tabular}

Tabel 3 terlihat bahwa nilai $X_{\text {hitung }}^{2}$ kelas eksperimen maupun kelas kontrol lebih kecil daripada nilai $X_{\text {tabel }}^{2}$. Artinya, hasil ini menunjukkan bahwa data pretest dan posttest kelas eksperimen maupun kelas kontrol terdistribusi normal. 


\section{Uji Homogenitas}

TABEL 4. HASIL UJI HOMOGENITAS PRETEST DAN POSTTEST KELAS EKSPERIMEN DAN KELAS KONTROL.

\begin{tabular}{cccccc}
\hline \multirow{2}{*}{ Uraian } & \multicolumn{3}{c}{ Pretest } & \multicolumn{2}{c}{ Posttest } \\
\cline { 2 - 6 } & Eksp & Kont & Eksp & Kont \\
\hline Nilai Varians & 8,14 & \multicolumn{2}{c}{11,99} & 12,05 & 10,81 \\
\hline Varians Hitung & \multicolumn{3}{c}{1,47} & \multicolumn{3}{c}{3,01} \\
\hline Nilai $F_{\text {tabel }}(\alpha=0,05)$ & \multicolumn{3}{c}{3,01} & \multicolumn{3}{c}{ Homogen } \\
\hline Keputusan & \multicolumn{3}{c}{ Homogen } &
\end{tabular}

Berdasarkan hasil output uji homogenitas pada Tabel 4 dengan taraf signifikan $(\alpha=0,05)$, dari data tersebut terlihat bahwa $F_{\text {hitung }}$ lebih kecil dari $F_{\text {tabel }}$, maka berdasarkan kriteria pengambilan keputusan dapat disimpulkan bahwa tidak terdapat perbedaan varians antara kelas eksperimen dan kelas kontrol atau dengan kata lain varians antara kelas eksperimen dan kelas kontrol adalah sama atau homogen.

4. Uji Hipotesis (Uji-t)

Data hasil pengujian statistik dapat dilihat pada Tabel 5.

TABEL 5. UJI-T PADA TES AWAL (PRETEST) DAN TES AKHIR (POSTTEST)

\begin{tabular}{lcc}
\hline \multicolumn{1}{c}{ Uraian } & Tes Awal (Pretest) & Tes Akhir (Posttest) \\
\hline$t_{\text {hitung }}$ & 0,05 & 3,18 \\
\hline$t_{\text {tabel }}(\alpha=0,05)$ & 2,00 & 2,00 \\
\hline Keputusan & $H_{0}$ diterima & $H_{0}$ ditolak \\
\hline
\end{tabular}

Berdasarkan data Tabel 5 diketahui pada tes awal (pretest) $t_{\text {hitung }} \leq t_{\text {tabel }}$ atau $0,05 \leq 2,00$. Hal ini menunjukkan bahwa nilai $t_{\text {hitung }}$ berada pada daerah penerimaan $H_{0}$. Dengan demikian maka $H_{1}$ ditolak, sehingga dapat dikatakan bahwa tidak terdapat perbedaan hasil belajar siswa antara kelas kontrol dan kelas eksperimen. Dan pada tes akhir (posttest) $t_{\text {hitung }} \geq t_{\text {tabel }}$ atau 3,18 $\geq 2,00$. Dalam artian nilai $t_{\text {hitung }}$ berada pada daerah penolakan $H_{0}$, dan $H_{1}$ diterima. Dapat disimpulkan bahwa terdapat pengaruh penggunaan alat konversi energi mekanik dalam model pembelajaran $P O E$ terhadap hasil belajar siswa. Dengan kata lain, hasil belajar kelas eksperimen lebih tinggi dibandingkan dengan kelas kontrol.

\section{Pembahasan}

Berdasarkan uji hipotesis terdapat pengaruh penggunaan alat konversi energi mekanik dalam model pembelajaran Predict, Observe, and Explain (POE).

Dengan menggunakan pembelajaran $P O E$ dan alat sederhana konversi energi mekanik untuk kelas eksperimen siswa lebih aktif dalam pembelajaran dimana siswa lebih berani untuk mengungkapkan hipotesis atau ramalan berdasarkan pengetahuan awal mereka. Dalam melakukan pengamatan konversi energi melalui metode eksperimen, siswa mampu menjelaskan hasil pengamatan mereka melalui diskusi. Diskusi dilakukan untuk menambah penjelasan ramalan atau hipotesis sebelumnya. Sedangkan untuk kelas kontrol hampir sama proses pembelajarannya hanya saja pada kelas kontrol hanya menggunakan model pembelajaran $P O E$ saja.
Melalui metode eksperimen siswa lebih memahami materi yang diajarkan karena siswa dapat melihat, membuktikan dan mengalami fenomena yang dipelajari karena pada kelas eksperimen siswa melakukan pembuktian sendiri melalui metode eksperimen dimana siswa mengamati konversi energi dari tenaga air menjadi energi listrik. Dengan demikian siswa lebih meyakini kebenaran materi pembelajaran dan mengingatnya dalam jangka waktu yang lama. Sehingga terdapat pengaruh penggunaan alat konversi energi mekanik dalam model pembelajaran $P O E$.

Hasil penelitian ini sejalan dengan penelitian sebelumnya dimana siswa sama-sama lebih aktif dalam pembelajaran, minat dan percaya diri siswa meningkat, dan hasil belajar siswa meningkat.

Kekurangan dalam penelitian ini adalah pada proses pembelajaran ketika memutar video animasi tidak berjalan dengan baik karena kelas yang digunakan tidak terdapat aliran listrik. Adapun kelebihan dalam proses pembelajaran dimana alat peraga yang digunakan tidak membutuhkan listrik sehingga alat peraga yang digunakan bisa digunakan diluar kelas.

\section{KESIMPULAN DAN SARAN}

\section{Kesimpulan}

Berdasarkan hasil penelitian yang diperoleh, maka dapat disimpulkan bahwa terdapat pengaruh penggunaan alat konversi energi mekanik dalam model pembelajaran $P O E$ terhadap hasil belajar siswa kelas VII SMP Negeri 15 Sigi. Hal ini ditunjukkan sesuai hasil pengujian hipotesis dimana nilai $t_{\text {hitung }}=3,18>t_{\text {tabel }}=2,00$ pada taraf signifikan $\alpha$ 
Pengaruh Penggunaan Alat Sederhana Konversi Energi Mekanik dalam Model Pembelajaran Poe Terhadap Hasil Belajar Siswa pada Materi Energi Kelas VII SMPN 15 Sigi

$=0,05$ dan derajat kebebasan, $\mathrm{dk}=60$ sehingga hipotesis dapat diterima.

\section{Saran}

Berdasarkan hasil penelitian yang diperoleh selama melakukan proses pembelajaran, maka penulis menyarankan:

1) Kepada guru bidang studi fisika agar dapat menerapkan alat sederhana dalam model pembelajaran $P O E$ pada materi-materi fisika yang menuntut adanya praktikum untuk meningkatkan hasil belajar siswa.

2) Bagi sekolah, penggunaan alat sederhana dalam model pembelajaran $P O E$ agar dapat dijadikan alternatif pembelajaran di sekolah untuk mata pelajaran lainnya.

3) Untuk peneliti selanjutnya dapat menerapkan alat sederhana dalam model pembelajaran $P O E$ dengan menggunakan metode-metode yang lebih inovatif.

\section{DAFTAR PUSTAKA}

(Liska Fajaryani)

[1] P. M. Restami. "Pengaruh Model pembelajaran POE (Predikct, Observe, and Explain Terhadap Pemahaman Konsep Fisika dan Sikap Ilmiah di Tinjau dari gaya Belajar Siswa". Jurnal Program Pasca Sarjana universitas Pendidikan Ganesha Program Studi IPA, Vol 3, 2013.

[2] Marwiah. "Peningkatan Pemahaman Belajar Fisika pada Siswa Kelas XD SMAN 9 Palu dengan pemanfaatan Alat-Alat Sederhana". Skripsi pada Fakultas KIP Universitas Tadulako: tidak diterbitkan, 2007.

[3] S. Paul. "Metodologi pembelajaran Fisika Konstruktivistik". Yogyakarta: universitas Sanata Dharma, 2007.

Sugiyono. "Metode Penelitian Kuantitatif, Kualitatif, dan R\&D". Bandung: Alfabeta, 2015 